DOI: $10.17805 /$ trudy.2018.4.9

\title{
СОВРЕМЕННОЕ ПРЕДСТАВЛЕНИЕ О НРАВСТВЕННОМ ВОСПИТАНИИ СТУДЕНЧЕСКОЙ МОЛОДЕЖИ
}

\author{
Л. С. Агеева \\ Московский гуманитарный университет
}

\begin{abstract}
Аннотация: ВВ статье рассмотрены особенности нравственного воспитания студентов. Дана характеристика студенческой молодежи и нравственного воспитания данного возраста. Представлены современные особенности воспитания нравственности в России.
\end{abstract}

Ключевые слова: нравственность, воспитание, студенческая молодежь, воспитание нравственности, юность, молодежь, рефлексия, инновационные технологии

\section{CONTEMPORARY INSIGHT INTO MORAL EDUCATION OF MODERN STUDENTS}

\author{
L. S. Ageyeva \\ Moscow University for the Humanities
}

\begin{abstract}
The article deals with the features of moral education of students. It gives the characteristic of students and moral education of this age group. The author presents some contemporary peculiarities of moral education in Russia.
\end{abstract}

Keywords: morality; education; students; moral education; youth, young people; reflection; innovative technologies

На современном этапе развития общества происходит ослабление, а в некоторых случаях полное отсутствие нравственных представлений, приводящих к персонализации интересов, итогом которой может стать деградация общественных отношений. Сегодня данным вопросом обеспокоена и российская власть, и ученые. 29 мая 2015 г. в стране была разработана Стратегия развития воспитания в Российской Федерации на период до 2025 года (Стратегия развития ... , Электронный ресурс). Эта Стратегия послужила началом поиска наиболее эффективных путей решения данной проблемы.

Современные психологические, педагогические и социологические исследования характеризуют ушедший XX век в России как век материализма (Ильинский, 2016; Надточий, Надточий, 2017; Луков, 2018: Электр. 
Научные труды Московского гуманитарного университета 2018 № 4

ресурс). Общество представляло собой некое «производственное объединение» - это был ответ на сложившийся экономический кризис в России. Что способствовало воспитанию у современной студенческой молодежи экономического духа и потребительского взгляда на жизнь. Конечно, не стоит уменьшать значимость экономической составляющей жизни и не брать в расчет посткризисное состояние современной России, но человеческая жизнь должна состоять в балансе материального и нравственного составляющего в обществе. Результат данных изменений заметен в подрастающем поколении (Надточий, Надточий, 2017) .

Основным мотивов выбора той или иной сферы деятельности, а в дальнейшем организации, компании, в которой предстоит трудиться молодому специалисту, становится получаемая заработная плата и престижность профессии. В научных исследованиях Н. В. Кокоевой, современный студент описывается как личность, ощущающая нестабильность своего социально-профессионального положения, после окончания вуза он испытывает неуверенность в своей востребованности обществом как профессионала, в связи с тем, что специалистов определенных направлений становится все больше, а «невостребованные» профессии постепенно входят в упадок. Это хорошо заметно на таких раньше популярных профессиях как космонавт, учитель, ученый, врач, художник, музыкант, социальный работник. Данные профессии требуют не только определенного таланта, но и сильную включенность специалистов во взаимоотношения с другими людьми на уровне духа. Приставленные направления можно назвать «дающими», то есть через эти профессии общество получает новую информацию, новые открытия на уровне общих достижений человечества. Труд перестает восприниматься как ценность, а основной ценностью становятся деньги как фактор успешной реализации личности. В свою очередь студенты, опирающиеся на экономически выгодные профессиональные направления, перестают ориентироваться на свои природные таланты и делают выбор в пользу престижной профессии. Что может привести к нереализованности в будущем и депрессивным состояниям из-за вынужденного выполнения неинтересного и тяжелого для личности профессионального труда, а в дальнейшем и к общей потере интереса в жизни (Кокоева, 2013: 150-152).

Поэтому одной из главных проблем сегодняшней действительности становится утрата критериев нравственности в экономической жизни общества, а как итог во всех сферах жизни деятельности человека. Наиболее остро данный кризис ощущается в поведении подрастающего поколения, а именно в период юности.

Социально-психологические характеристики студенческой молодежи отличаются от детей и взрослых, в том числе спецификой их представлений 
об окружающей действительности. Молодежь как социально-возрастная группа наиболее полно охарактеризована в возрастной психологии юношества. В западной психологии данной проблемой занимались такие известные ученые как: Э. Эриксон, Ж. Пиаже, М. Мид, К. Левин и др. Отечественная психология получила представления о юношеском возрасте благодаря трудам ведущих психологов, педагогов и социологов таких как: С. Л. Рубинштейн, Л. С. Выготский, И. С. Кон, Д. Б. Эльконин, А. В. Мудрик, и др. Само направление психологии молодежи возникло в начале XX века, а эмпирические исследования проводились еще до Первой мировой войны. Однако на сегодняшний день молодежь как социально-психологическое явление изучено недостаточно.

Молодежь как социальный феномен имеет характерные черты, определяющиеся возрастными рамки, которые обозначены границами подросткового и юношеского возраста (от 15 до 24 лет).

Понятия «возраст» в психолого-педагогической литературе представлено как конкретная ступень становления индивида и его психологического развития как личности, ограниченная во временном периоде, которая характеризуется совокупностью имеющихся физиологических, психических и социальных изменений (Фельдштейн, 1996: 53). На основании анализа итогов Всероссийской переписи населения за 2010 г. были выявлены границы юношеского возраста в пределах от 15 до 24 лет (Основные итоги ..., Электр. ресурс). Окончание подросткового периода в последние годы часто меняется. Это связано с современными тенденциями: молодежь дольше живет с родителями, поэтому их подростковый возраст затягивается (Ильинский, 2016: 5-12). Современные ученые выделяют два периода данного этапа развития личности: первый период имеет границы с 15 до 17 лет и второй-с 17 до 24 год (Абульханова-Славская, 1999: 25).

В нашем исследовании особое внимание уделяется 2-му периоду «юности», так как именно в этот период школьники поступают в вузы и переходят в категорию «студенческой молодежи». Однако не стоит забывать о том, что некоторые становятся студентами и с 15 до 17 лет, поступая в колледжи или техникумы.

Вторую фазу подросткового возраста Д. Б. Эльконин определяет как направленную на учебно-профессиональную деятельность (Эльконин, 1989: 46-53). Личное и социальное самоопределение в этот возрастной период активизирует выработку собственного представления о мире, индивидуальной жизненной позиции и развитие интегральных механизмов самосознания (Кон, 1989: 67-68). И. В. Дубровина подчеркивает особенность студенческого возраста - расширение мировоззрения «вглубь» и «вширь», как личных, так и социальных перспектив (Дубровина, 2013: 42). 
Научные труды Московского гуманитарного университета 2018 № 4

Первым из исследователей, кто отметил психологический переход от детства к взрослости, как открытие второго «Я» и развитие самосознания, был Э. Шпрангер. После него практически все ученые подтвердили данные изменения в личности (Шпрангер, 1980: 286-300).

Особенностью юношеского возраста являются такие личностные составляющие как рефлексия и интроспекция. Это связанно с формированием у личности в данном возрастном периоде ценностных ориентаций, взглядов и привычек, определяющих стратегию людей в личностных и общественных отношениях (Батарчук, 2016). В связи с этим «переходный возраст» является наиболее сенситивным для нравственного воспитания. В мировоззренческих поисках студенческой молодежи именно развитие рефлексии находит свое выражение в поиске смысла жизни. В этот возрастной период личность пытается «разом осмыслить, и собственное существование, и перспективы развития общества» (Кон, 1999: 55).

В этой связи навык постоянного саморазвития становится основной целью образовательного процесса при формировании у студенческой молодежи критериев нравственности (Джига, 2009). Оценка эффективности развития данного навыка у личности осуществляется именно на основе рефлексивного подхода (Гимпель, 2010: Электр. ресурс). В исследованиях Е. Г. Беляковой раскрыты этапы реализации рефлексии: на первом этапе актуализируются смысловые структуры личности в момент оценки ею возникшей проблемной ситуации; второй этап представляет собой использование данных смыслов в апробировании деятельности и опыта личности; третий этап характеризуется дискредитацией смыслов на основе выделенных личностных противоречий; на четвертом этапе происходит преодоление данных противоречий и выработка нового осмысления личностью проблемной ситуации по средствам инновационных и конструктивных представлений; пятый заключительный этап является реализацией новых представлений в жизнь и дальнейшее коррекция собственного опыта для оптимального выхода из данной проблемной ситуации (Белякова, 2010: 44-48). Пройдя основные этапы рефлексивного механизма, личность становится способна не только с помощью педагога определять и развивать критерии нравственности, но и самостоятельно контролировать свою нравственную мотивацию, вербализацию и нравственное поведение в обществе.

Основной проблемой, стоящей перед педагогическим коллективом вуза на начальном этапе воспитания нравственности, становится формирование у молодого поколения мотивации к познанию и освоению критериев нравственности. Эта мотивация сложна именно тем, что должна идти изнутри самого воспитуемого. Учитывая эту особенность, для решения данной проблемы нами была выбрана экзистенциальная педагогика, которая от- 
личается свободой выбора усвоения тех или иных знаний самим учащимся. Феномен экзистенция представляет собой процесс обретения собственного «Я», преодоление инертности существования и способ личного проживания. Таким образом, самопознание становится главной основой экзистенции, которая проходит через ответственность за свои поступки и выбор своего пути. Педагогические положения экзистенциализма представляют собой отношение к личности как к уникальной, которая черпает свои знания из внутреннего «Я», где источником выступает творчество, опыт и сами знания об окружающем мире. Преподаватель, использующий данную педагогику для формирования мотивации к развитию критериев нравственности, подает материал, основываясь на внутренних мотивах каждого учащегося, исходя из возрастных особенностей и диагностических методик, определяющих особенности каждого студента.

Сократическая и эвристическая беседа становится основным методом мотивирования студенческой молодежи к познанию критериев нравственности. Данный диалог основывается на интуиции и озарении. Такое представление меняет привычное отношение к нравственности в целом, оно снимает пугающую и давящую установку «Ты должен» в обществе, на осознанный выбор своей позиции через установки «Я хочу» и «Я могу». Именно это становится основой формирования мотивации педагогом к критериям нравственности (Блохина, 2018).

Описанные нами особенности нравственного воспитания студенческой молодежи на основе рефлексивного подхода требуют использование технологий высшего порядка. Е. В. Белова и В. А. Прохорова представляют инновационные технологии как технологии более высокого уровня. Когда данные технологии, заложенные в учебный процесс, влияют на специфику приемов, методов и способов, которые составят этапы технологий низшего порядка. Основой инновационной технологии становиться активизация ценностно-смысловой сферы личности, то есть речь может идти о таком феномене как «рефлексия». Данные технологии получили название рефлексивные технологии. Эти педагогические технологии выполняют функцию «раскрытия смысла». Это раскрытие относится к содержанию, которое пока не открыто обучающемуся смысла не несет самоценность. Также и рефлексивная технология лишь позволяет создать условия для раскрытия того или иного смысла для обучающегося и трансформировать его в дальнейшую деятельность или в учебный процесс.

Данные технологии способствуют развитию тесного контакта педагога с обучающимися, помогает преподавателю сформировать у студенческой молодежи отношение к себе как к неформальному лидеру группы, что наиболее актуально в работе с юношеским возрастом. В данном случае педагог 
Научные труды Московского гуманитарного университета 2018 № 4

не дает ответы на задаваемые вопросы, а находит их вместе со студентами, только направляя их мыслительный процесс в нужном русле (Прохорова, Белова, 2009).

Инновационные технологии, выбранные нами, решают задачу вуза в создании условий, при которых будущее поколение смогло бы совершенствовать самих себя, нашло бы свое место существования в современном мире, открыло бы новые свойства своей личности.

На основе проведенного нами анализа психолого-педагогической литературы нами были выделены следующие условия для воспитания нравственности студенческой молодежи: особенности личности в данный возрастной период (студенческая молодежь), что в свою очередь переходит в особенность выбора подхода к воспитанию (рефлексивный подход), а затем к выбору наиболее подходящих технологий для данного процесса (инновационно-рефлексивные технологии). Предлагаемые нами условия, основанные на рефлексивном подходе, способствуют: увеличение мотивации к самовоспитанию у личности критериев нравственности; становлению навыка саморазвития (самомотивацией, самокоррекцией, саморефлексией) студентов; увеличению эффективного овладения учащимися необходимыми нравственными действиями по отношению к другим людям, что способствует в свою очередь увеличению уровня нравственного развития общества в целом, так как студенческая молодежь является основой нашего будущего общества.

\section{СПИСОК ЛИТЕРАТУРЫ}

Абульханова-Славская, К. А. (1999) Психология и сознание личности (Проблемы методологии, теории и исследования реальной личности): избранные психологические труды. М. : Моск. психолого-социальный ин-т. ; Воронеж : Изд-во НПО «МОДЭК». 224 с.

Батарчук, Д. С. (2016) Исследование рефлексии и толерантности студенческой молодёжи в условиях этнической диверсификации региона // Акмеология. № 3 (59). С. 116-121.

Белякова, Е. Г. (2010) Модель смыслоориентированного образования // Знание. Понимание. Умение. № 3. С. 44-48.

Блохина, А. В. (2018) Сущность становления личности будущих педагогов с точки зрения экзистенциальной педагогики // Вестник Российского нового университета. Серия «Человек в современном мире». № 2. С. 27-30.

Гимпель, Л. П. (2010) Педагогическая рефлексия в структуре профессиональной деятельности // Личность, семья и общество: вопросы пе- 
дагогики и психологии: сб. ст. по матер. I междунар. науч.-практ. конф. № 1. Часть I. [Электронный ресурс] // СибАк. URL: https://sibac.info/conf/ pedagog/i/35242 (дата обращения: 03.09.2018).

Джига, Н. Д. (2009) Самоуправление, самоизменение личности студента как фактор успешности развития // Знание. Понимание. Умение. № 3. С.206-210.

Дубровина, И. В. (2013) Психологическая культура личности в структуре профессиональной компетентности // Гуманизация образования. № 5. C.40-47.

Иванов, Д. А. (2008) Компетенции и компетентностный подход в современном образовании // Завуч: управление современной школой. № 1 . C.4-24.

Ильинский, И. М. (2016) Воспитание новых поколений: назревшие проблемы // Знание. Понимание. Умение. № 2. С. 5-12.

Кокоева, Н. В. (2013) Формирование нравственной культуры у будущих специалистов в педагогическом вузе // Сибирский педагогический журнал. № 2. С. 150-152.

Кон, И. С. (1989) Психология ранней юности. М. : Просвещение. 256 с.

Кон, И. С. (1999) Социологическая психология. М. : Воронеж. 560 с.

Луков, В. А. (2018) Молодеющее общество: эскиз тезаурусной концепции [Электронный ресурс] // Горизонты гуманитарного знания. № 1. URL: http://journals.mosgu.ru/ggz/article/view/699 (дата обращения: 12.06.2018). DOI: 10.17805/ggz.2018.1.1

Надточий, И. О., Надточий, С. О. (2017) Социально-экономические преобразования и проблемы нравственного воспитания учащейся молодежи // Вестник Воронежского института высоких технологий. № 1 (20). С. 146-150.

Прохорова, А. В., Белова, Е. В. (2009) Рефлексивные технологии: перспективы использования в обучении студентов // Северо-Кавказский психологический вестник. Педагогическая психология. № 7/3. С. 11-16.

Фельдштейн, Д. И. (1996) Психология развивающейся личности. М. : МПСИ ; Воронеж : НПО «МОДЭК». 208 с.

Эльконин, Д. Б. (1989) Избранные психологические труды. М. : Педагогика. 560 с.

Ягяджик С. С. (2016) Виды инновационных технологий и их характеристики [Электронный ресурс] // Молодой ученый. № 23. URL: https://moluch. ru/archive/127/35057/ (дата обращения: 06.08.2018).

Основные итоги переписи населения 2010 года [Электронный ресурс]// Федеральная служба государственной статистики. URL: http://www.gks.ru/ free_doc/new_site/perepis2010/croc/perepis_itogi1612.htm (дата обращения: 06.09.2018). 
Стратегия развития воспитания в Российской Федерации на период до 2025 года [Электронный ресурс] // Российская газета. URL: https:// rg.ru/2015/06/08/vospitanie-dok.html (дата обращения: 06.08.2018).

Дата поступления: 14.08.2018 2.

Агеева Любовь Сергеевна - заведующая отделом организации научных мероприятий управления науки, аспирантуры и докторантуры и научной работы; аспирант кафедры педагогики и психологии высшей школы Московского гуманитарного университета. Адрес: 111395, Россия, г. Москва, ул. Юности, д. 5, корп. 6. Тел.: +7 (499) 374-75-40. Эл. адрес: Lburdyakova@ mosgu.ru. Научный руководитель - д-р пед. н., проф. Л. В. Романюк.

Ageeva Lubov' Sergeevna, Head, Department of Organization of Scientific Events, Department of Science, Postgraduate and Doctorate Studies and Scientific Research; Postgraduate Student, Department of Pedagogy and Psychology of Higher School, Moscow University for the Humanities. Postal address: 5, Yunosti St., Moscow, Russian Federation, 111395. Tel.: +7 (499) 374-75-40. E-mail: Lburdyakova@mosgu.ru. Scientific Adviser - L. V. Romanyuk, Doctor of Pedagogy, Professor.

\section{Для цитирования:}

Агеева Л. С. Современное представление о нравственном воспитании студенческой молодежи [Электронный ресурс] // Научные труды Московского гуманитарного университета. 2018. № 4. URL: http://journals.mosgu. ru/trudy/article/view/813 (дата обращения: дд.мм.гг.). DOI: 10.17805/ trudy.2018.4.9 